\title{
A CASE OF CELIAC DISEASE PRESENTING WITH RECURRENT ATTACKS OF QUADRIPARESIS
}

\author{
HOSSAIN MZ ${ }^{1}$, HASAN ${ }^{2}$, FERDOUS ${ }^{3}$, MOZAZFIA KT ${ }^{4}$, HOSSAIN MM ${ }^{5}$, TOWHID KMS ${ }^{6}$, \\ PATWARY MSA ${ }^{7}$
}

\begin{abstract}
Celiac disease, once considered a rare disease in Bangladeshi population, have recently been reported more frequently. Recognition of celiac disease is not easy and a high degree of suspicion in required. Although the disease presents usually with malabsorption syndromes, atypical presentations also may occur which may cause confusion in making a prompt diagnosis. We intend to report a case who presented primarily with flaccid type of quadriparesis who ultimately was proven to be a case of celiac disease. Although neurological symptoms have been associated with celiac disease, motor weakness is very uncommon. We have proposed that in our case electrolyte imbalance have caused or contributed in causing this motor weakness.
\end{abstract}

Keywords: Celiac disease, Recurrent weakness

J Dhaka Med Coll. 2016; 25(2) : 138-141

\section{Introduction}

Celiac disease, once considered a rare disease in Bangladeshi population, have recently been reported more frequently. ${ }^{1}$ Recognition of celiac disease is not easy and a high degree of suspicion in required. ${ }^{2}$ Although the disease presents usually with malabsorption syndromes, atypical presentations also may occur which may cause confusion in making a prompt diagnosis. We intend to report a case who presented primarily with flaccid type of quadriparesis who ultimately was proven to be a case of celiac disease.

\section{Case report}

A Bangladeshi Muslim male, aged 22 years, non-diabetic, normotensive patient was admitted in the hospital on 16 March 2016 with the complaints of chronic diarrhea for 2 months, weakness of all four limbs and muscle cramp for same duration. he had been previously admitted on 01 March 2016 in a clinic with above complaints along with flaccid quadriparesis. There his serum electrolyte profile revealed severe hypokalemia (his electrolytes level are given in the Table 1). They attributed his weakness to hypokalemic periodic paralysis as the patient gave history of recurrent episodes of concomitant diarrhea and such quadriparesis and treated him. After some recovery of limb functions, they referred the patient to $\mathrm{DMCH}$ for further management and to search for specific cause of hypokalemia because of the severity and persistence of symptoms. The patient also reported about loss of $10 \mathrm{Kg}$ weight within 2 years.

The patient had no relevant family history. He is non-smoker, non-alcoholic and used to live for 2 years in Malaysia 1.5 year back as an immigrant student. His HIV p24 Ag and HIV Ab tests were done which were negative. He had consulted his gastroenterologist 7 months back and had been suspected and treated for tropical sprue, but no significant improvement was seen. His thyroid hormone profile had been done which had been within normal range excluding hyperthyroidism induced diarrhea.

1. Dr. Mohammad Zaid Hossain, Associate Professor, Department of Medicine, Dhaka Medical College, Dhaka

2. Dr. Pratyay Hasan, Indoor Medical Officer, Department of Medicine, Dhaka Medical College Hospital, Dhaka

3. Dr. Kainat Ferdous, Medical Officer, Department of Medicine, Dhaka Medical College Hospital, Dhaka.

4. Dr. Kazi Tuba-E Mozazfia, Assistant Registrar, Department of Medicine, Shaheed Suhrawardy Medical College, Dhaka.

5. Dr. Md. Murad Hossain, Assistant Professor, Department of Medicine, Dhaka Medical College, Dhaka.

6. Dr. Kazi Md. Saleheen Towhid, Indoor Medical Officer, Department of Medicine, Dhaka Medical College Hospital, Dhaka.

7. Dr. Mohammad Shamsul Arefin Patwary, Registrar, Department of Medicine, Dhaka Medical College, Dhaka Correspondence: Dr. Mohammad Zaid Hossain Associate Professor, Department of Medicine, Dhaka Medical College, Dhaka, Email: zhvalentino@gmail.com 
Table 1

Changes in serum electrolytes over time.

\begin{tabular}{|c|c|c|c|c|c|c|}
\hline Serum electrolytes & $12 / 03 / 16$ & $13 / 03 / 16$ & $14 / 03 / 16$ & $15 / 03 / 16$ & $16 / 03 / 16$ & $27 / 03 / 16$ \\
\hline Sodium (mmol/L) & 133 & 136 & 133 & & & 138 \\
\hline Potassium (mmol/L) & 1.3 & 1.5 & 1.6 & & & 3.8 \\
\hline Calcium (mg/dL) & & & & & 7.3 & \\
\hline Magnesium (mg/dL) & 1.1 & & & 1.5 & 1.6 & \\
\hline Chloride $(\mathrm{mmol} / \mathrm{L})$ & 97 & 100 & 100 & & & 104 \\
\hline
\end{tabular}

On admission, his general examination revealed: pulse-88/min, blood pressure-100/ $60 \mathrm{~mm}-\mathrm{Hg}$, temperature- $98.2^{\circ} \mathrm{F}$, respiratory rate- 13 breaths/min, mildly anemic, nonicteric, ill-looking appearance. His nervous system examination revealed- diminished limb jerks along with muscle power $(3 / 5)$ on all four limbs. Other systemic examinations were nonremarkable.

His investigation findings were, $\mathrm{Hb}-11.8 \mathrm{mg} /$ $\mathrm{dL}, \mathrm{WBC}-12,600 / \mathrm{mm}^{3}$, ESR - 25mm, USG of whole abdomen- gall bladder sludge, chest $\mathrm{x}$ ray $\mathrm{P} / \mathrm{A}$ view- normal study, urine $\mathrm{R} / \mathrm{E}$ and urine culture- normal, fasting blood glucose $4.9 \mathrm{mmol} / \mathrm{L}$ and 2 hours after $75 \mathrm{~g}$ glucose intake level- $5.7 \mathrm{mmol} / \mathrm{L}$. Serum albumin 2.6 $\mathrm{g} / \mathrm{dL}$, serum creatinine-0.84, SGPT - $65 \mathrm{u} / \mathrm{L}$. His investigation profile suggested, he was found with persistent low level of several electrolytes such as sodium and potassium, (shown in Table 1), but his urinary electrolyte levels were all lower than the normal range. Which signifies that the loss of electrolytes was not due to urinary loss, but considered together with his history of recurrent diarrhea, they were due to gastrointestinal loss. To assess the possibility of several diseases causing different malabsorption syndromes, stool R/E, endoscopy and colonoscopy etc. were done. Stool R/E showed only mucus (+). Although he gave no history of TB, to exclude the possibility of intestinal TB, both Quantiferon TB gold test and Mantoux test were also done and found negative. At this point celiac disease was considered and anti-TTG Ab titer was found$52.3 \mathrm{u} / \mathrm{mL}$ (cut off value $50 \mathrm{u} / \mathrm{mL}$ ). Colonoscopy did not reveal any abnormality. Biopsy taken by upper GI endoscopy, showed total villous atrophy with increased number of goblet cells in the lining mucosa and dense infiltration of lymphoid cells in the lamina propria, forming follicles in some areas. The lymphoid cells have infiltrated the mucosa in some areas. Thus the endoscopic findings were suggestive of celiac disease.

\section{Discussion}

There are several different approaches for diagnosing celiac disease, but usually all of them require presence of serologic evidence e.g. anti TTG antibody, positive biopsy findings and change in clinical features and serology with exposure to or withdrawal of gluten. ${ }^{3}$ Leffler et.al. has proposed a similar approach, in their "Proposed Modified Gluten Challenge Algorithm" where positivity of baseline serology indicates probable celiac disease, and then subsequent positive duodenal biopsy confirms the diagnosis. ${ }^{4}$ But, according to proposition of Leffler et.al., negative baseline serology does not exclude the diagnosis of celiac disease, but rather it demands HLA DQ2/DQ8 testing, and if the patient has susceptible HLA DQ2/DQ8 pattern, a gluten challenge test is done with three gram of gluten per day for 2 to 6 weeks, which may bring out characteristic serological changes and histological changes in biopsy. ${ }^{4}$ Multiple biopsies should be obtained from the duodenal bulb and the second and third portion of the duodenum. ${ }^{5,6}$ There are differences of opinions as for to the number of biopsies to make a certain diagnosis of celiac disease but, 4 to 6 biopsies are recommended by some. ${ }^{7,8}$ Pais et.al. have suggested that only 2 biopsy specimens will lead to a confirmed diagnosis of $\mathrm{CD}$ in $90 \%$, and a suspected diagnosis in all, but for $100 \%$ confidence in diagnosis of $C D, 4$ 
duodenal biopsy specimens should be taken. ${ }^{9}$ Here it can be noted that antibodies have a great role in diagnosis of celiac disease. IgA tissue transglutaminase antibodies has a sensitivity of 90 to 98 percent and a specificity of 95 to 97 percent. ${ }^{10}$ Nonetheless, a positive antibody test suggests that a person might have celiac disease, but to confirm, a biopsy will be needed. ${ }^{11}$ Peripheral neuropathies maybe found in up to 50 percent of patients with celiac disease and may precede its diagnosis. Ludvigsson et.al. reported in a large populationbased study from Sweden that included 14,000 celiac patients and 70,000 controls, that celiac disease was associated with an increased risk of polyneuropathy (hazard ratio 3.4), but not with other neurologic outcomes. ${ }^{12}$ They also recommended that individuals with polyneuropathy should routinely undergo screening for $\mathrm{CD} .{ }^{12}$ In our case, the patient presented with recurrent attack of quadriparesis. Instances of such manifestation of celiac disease is truly rare, although have been reported in recently published medical literature a very few times. ${ }^{13-15}$ Celiac disease is a rare cause of neuropathy that most commonly presents with symmetric distal sensory disturbances. ${ }^{15,16}$ Neurologic manifestations, such as ataxia and peripheral neuropathy, are increasingly recognized to be the presenting features of CD. ${ }^{17}$ Hadjivassiliou et.al. described 9 patients with neuromuscular disorders with $\mathrm{CD}, 3$ patients had sensorimotor axonal peripheral neuropathy, 1 had axonal motor peripheral neuropathy, 1 had probable inclusion body myositis and axonal motor peripheral neuropathy, 1 had polymyositis and sensorimotor peripheral neuropathy, 1 had mononeuropathy multiplex, 1 had neuromyotonia, and 1 had polyneuropathy. ${ }^{18}$ Hernandez and Green reported neurologic and psychiatric disorders associated with celiac disease include cerebral ataxia, peripheral neuropathy, epilepsy, dementia, and depression. ${ }^{19}$ As for the mechanism of neurological manifestations of $\mathrm{CD}$, current data point to molecular mimicry and intermolecular help as two possible mechanisms. ${ }^{17}$ Rigamonti et.al. described two patients in whom celiac disease was diagnosed after the onset of peripheral neuropathy characterized by predominant motor nerve involvement in whom, after a gluten-free diet, significant improvement of symptoms and neurophysiological findings occurred. ${ }^{15}$ In our case, changes in serum electrolytes may reflect the reason why our patient suffered from quadriparesis due to hypokalemic periodic paralysis. The only known instance of such phenomenon was found in India. ${ }^{14}$

\section{Conclusion}

Although neurological symptoms have been associated with celiac disease, motor weakness is very uncommon. We have proposed that in our case electrolyte imbalance have caused or contributed in causing this motor weakness.

\section{Conflict of interest: None}

\section{References}

1. Kabir A, Deb SR, Akhter R, Bhuyian MR, Hasan P. Diagnostic delay in clinical practice: A case report of Coeliac disease. Bangabandhu Sheikh Mujib Med Univ J. 2016 Aug 5;7(1):68-70.

2. Dubé C, Rostom A, Sy R, Cranney A, Saloojee N, Garritty $\mathrm{C}$, et al. The prevalence of celiac disease in average-risk and at-risk Western European populations: A systematic review. Gastroenterology. 2005 Apr;128(4, Supplement 1):S57-67.

3. Binder HJ. Disorders of absorption. In: Kasper DL, Fauci AS, Hauser S, Longo D, Jameson JL, Loscalzo J, editors. Harrison's Principles of Internal Medicine. 19th ed. Philadelphia: McGraw Hill Professional; 2015. p. 1932-46.

4. Leffler DA, Schuppan D, Pallav K, Najarian R, Goldsmith JD, Hansen J, et al. Kinetics of the histologic, serologic and symptomatic responses to gluten challenge in adults with coeliac disease. Gut. 2013 Jul;62(7):996-1004.

5. Evans KE, Aziz I, Cross SS, Sahota GRK, Hopper $A D$, Hadjivassiliou $M$, et al. A prospective study of duodenal bulb biopsy in newly diagnosed and established adult celiac disease. Am J Gastroenterol. 2011 Oct;106(10):1837-1742.

6. Kurien M, Evans KE, Hopper AD, Hale MF, Cross SS, Sanders DS. Duodenal bulb biopsies for diagnosing adult celiac disease: is there an optimal biopsy site? Gastrointest Endosc. 2012 Jun;75(6):1190-6.

7. Green PHR, Cellier C. Celiac disease. N Engl J Med. 2007 Oct 25;357(17):1731-43. 
8. Ludvigsson JF, Leffler DA, Bai JC, Biagi F, Fasano A, Green PHR, et al. The Oslo definitions for coeliac disease and related terms. Gut. 2013 Jan;62(1):43-52.

9. Pais WP, Duerksen DR, Pettigrew NM, Bernstein CN. How many duodenal biopsy specimens are required to make a diagnosis of celiac disease? Gastrointest Endosc. 2008 Jun;67(7):1082-7.

10. Kelly CP, Feighery CF, Gallagher RB, Gibney MJ, Weir DG. Mucosal and systemic IgA anti-gliadin antibody in celiac disease. Dig Dis Sci. 1991;36(6):743-751.

11. Screening for celiac disease | University of Chicago Celiac Disease Center [Internet]. [cited 2017 Apr 3]. Available from: http:// www.cureceliacdisease.org/screening/

12. Ludvigsson JF, Olsson T, Ekbom A, Montgomery SM. A population-based study of coeliac disease, neurodegenerative and neuroinflammatory diseases. Aliment Pharmacol Ther. 2007 Jun 1;25(11):1317-27.

13. Demirci S, Cengizhan E, Karahan N. Celiac Disease Presenting with Motor Weakness. J Turgut Ozal Med Cent. 2012 Dec 15;19(4):264-7.
14. Ranjan A, Debata PK. A Case of Periodic Hypokalemic Paralysis in a Patient with Celiac Disease. J Clin Diagn Res JCDR. 2014 Jun;8(6):PD03-PD04.

15. Rigamonti A, Magi S, Venturini E, Morandi L, Ciano C, Lauria G. Celiac disease presenting with motor neuropathy: Effect of gluten free-diet. Muscle Nerve. 2007 May 1;35(5):675-7.

16. Chin RL, Sander HW, Brannagan TH, Green PHR, Hays AP, Alaedini A, et al. Celiac neuropathy. Neurology. 2003 May 27;60(10):1581-5.

17. Green PHR, Alaedini A, Sander HW, Brannagan $\mathrm{TH}$, Latov N, Chin RL. Mechanisms underlying celiac disease and its neurologic manifestations. Cell Mol Life Sci CMLS. 2005 Apr 1;62(7-8): 791-9.

18. Hadjivassiliou M, Chattopadhyay AK, DaviesJones G a. B, Gibson A, Grünewald RA, Lobo AJ. Neuromuscular disorder as a presenting feature of coeliac disease. J Neurol Neurosurg Psychiatry. 1997 Dec 1;63(6):770-5.

19. Hernandez L, Green PH. Extraintestinal manifestations of celiac disease. Curr Gastroenterol Rep. 2006 Sep 1;8(5):383-9. 